\title{
EXPLORING UNDERLYING DIMENSIONS OF UNEMPLOYMENT BENEFITS IN SLOVENIA AND ENTERPRISE-LEVEL IMPLICATIONS
}

\author{
Laura Južnik Rotar ${ }^{*}$ \\ Sabina Krsnik ${ }^{* *}$
}

Received: 12. 6. 2020

Preliminary communication

Accepted: 4. 2. 2022

UDC 331.567(497.4)

DOI https://doi.org/10.30924/mjcmi.27.1.4

\begin{abstract}
This paper aims to define the underlying dimensions of unemployment benefits in Slovenia using the principal component approach. We identified three determinants of unemployment benefits: the general economic environment, social protection, and the functioning of the labour market. Results of the research show that the poorer the general economic environment, the greater the pressure on unemployment benefits. Second, the more generous the social protection

on the labour market is, the higher the pressure on unemployment benefits. Third, poor functioning of the labour market increases the pressure on unemployment benefits, although the last effect was found not to be statistically significant.

Keywords: labour market, unemployment, social transfers, unemployment benefits, labour market policy

\section{INTRODUCTION}

The continuation of the global financial crisis in the second half of 2008 had severe consequences for Slovenia. There was a significant decline in general economic activity during the recession, most evident in the gross domestic product (GDP), employment, income, wholesale and retail sales, and industrial production. GDP declined by 7.5 percentage points and bottomed out in 2013 when it was 8.9 percentage points lower than in 2008. Numerous corporate bankruptcies and mass layoffs led to a $2.4 \%$ year-on-year decline in the labour force in 2009. According to the Statistical Office of the Republic of Slovenia, the number of

employed people reached its lowest level of 781,561 in January 2014. By the end of September 2018, 862,000 people were employed, i.e., the same number as in 2008 , before the crisis hit.

Moreover, the number of unemployed people increased significantly from 60,000 in 2008 to 96,000 by 2009 . With the second wave of the financial crisis in 2013, the number of unemployed increased significantly again. In January 2014, the number of unemployed reached its peak - 129,843 unemployed. In the following years, unemployment decreased. In 2019, on average 74,178 people were registered as

\footnotetext{
Laura Južnik Rotar, PhD, Associate professor, University of Novo Mesto, Faculty of Economics and Informatics, Na Loko 2, SI-8000 Novo Mesto, Slovenia, Phone: +386 7393 0026, E-mail: laura.juznik-rotar@uni-nm.si Slovenia, Phone: +386 7393 0037, E-mail: sabina.krsnik@gmail.com
}

** Sabina Krsnik, MSc, University of Novo Mesto, Faculty of Health Sciences, Na Loko 2, SI-8000 Novo Mesto,
\end{abstract}




\section{Journal of Contemporary Management Issues}

unemployed in Slovenia, which is still $14.8 \%$ more than in the pre-crisis period.

The number of recipients of unemployment benefits in Slovenia increased dramatically in 2009 due to the financial crisis. In the first year alone, the number of claimants rose from 14,000 people to more than 27,000 . Due to the increasing proportion of unemployed and recipients of unemployment benefits, the government had to take appropriate measures. According to many economists, structural reforms and labour market reforms help improve the labour market conditions and achieve greater prosperity on the labour market (Kajzer, 2015). Structural reforms are changes that adjust the economic system and the institutional and administrative structure in which businesses and people operate. They often address obstacles related to growth drivers processes, such as reorganising labour markets, products and services, and financial markets, ensuring job creation, and contributing to productivity. If structural reforms are well-chosen and put into practice, they can accelerate the process of upward economic and social convergence. The Slovenian government has implemented numerous critical structural reforms in recent years to increase economic growth. It is essential to keep in mind that economic conditions also influence the impact of the reforms and that the short- and long-term effects may vary (Bouis et al., 2012). To assess the impact of labour market reforms, it is essential to understand that there was a turnaround in economic activity following the implementation of the changes. After 2014 , the number of registered unemployed persons began to decline, with the number of recipients of unemployment benefits.

In addition, labour market policy is a critical regulator of the labour market and aims to reduce unemployment and improve employment (Južnik Rotar, 2011). There are two types of measures within labour market policy: active and passive labour market policy. Active labour market policy (ALMP) aims to provide unemployed people with better chances of finding a job, e.g. through education, training, subsidised employment etc. In contrast, passive labour market policy (PLMP) are cash transfers that enable unemployed people to compensate for income losses. Comparing active and passive labour market policies, the latter accounts for more than $70 \%$ of total labour market policy spending and can lead to long-term unemployment (Martin, 2014). Therefore, the activation of the unemployed is of great importance.

A significant challenge for the economic policy decision-makers is to increase the volume of work, which would significantly improve the situation in the labour market. Due to demographic changes, especially the ageing of the population, faster activation and integration of the unemployed is necessary. Such a policy orientation would help reduce dependence on social transfers, allocate labour resources better, increase national output, and, consequently, use public resources more effectively through evidence-based policymaking.

This paper contributes to the literature by examining the underlying dimensions of unemployment benefits using the principal component approach, thus contributing to evidence-based policymaking. This research contributes to a better understanding of the Slovenian labour market and unemployment benefit system. The research findings can benefit economic policy decision-makers in designing and implementing such a labour market policy that promotes work instead of social transfers, that supports activation of the unemployed, that, in interaction with the tax system, sends 
a clear message that it is more beneficial to work than to rely on and depend on social assistance and other transfers for the unemployed.

The structure of the paper is as follows. In the second section, we provide a literature review to present the theoretical basis of our empirical research. We then present the data and methods used in the empirical investigation. The fourth section offers the results, while the fifth section discusses the implications. The last section concludes the paper.

\section{LITERATURE REVIEW}

Although the economic effects of unemployment benefits have been the subject of much research, they remain poorly understood. The effects of extensive economic outcomes such as employment levels, unemployment rates, job openings, and worker wages are unexplained and highly problematic, especially in the context of the Great Recession. The majority of empirical studies have focused on assessing the impact of individual variables on labour market outcomes. Despite extensive literature on the impact of unemployment protection systems on labour market outcomes, no consensus has been reached on the direction and magnitude of the effect (see, e.g., Vodopivec et al., 2017).

High unemployment means that the economy is working below its total capacity and is inefficient, leading to lower incomes and lower overall output. The fewer people are working and thus producing products and services, the lower the economy's output. One of the studies suggests that the associated decline in GDP growth can be about two percentage points for every percentage point increase in the unemployment rate (Owyang and Sekhposyan, 2012). More extended periods of unemployment lead to more considerable GDP losses (Gonshorowski and Greszler, 2020). During economic expansion, when aggregate demand increases, new jobs are created, which leads to a decrease in unemployment, and affects the number of recipients of unemployment benefits. Unemployment leads to increased government spending in the form of social safety net programmes while reducing government revenues. Fewer people in the labour force leads to declining incomes and tax revenues, lower consumer spending, declining sales taxes, and deteriorating corporate profits (Gonshorowski and Greszler, 2020).

Unemployment benefit programmes support economic structural change toward higher productivity and promote worker mobility and retraining in the labour market (Behrendt, 2013; Berg and Salerno, 2008). Unemployment benefits are an effective tool to avoid the devaluation of skills and protect human capital, mainly because they can mitigate evolution and improve workers' productive skills. Laporšek and Dolenc (2011) and Bekker (2018) analysed the relationship between labour productivity and flexicurity in EU countries and found a significant relationship. They showed that rigid labour market regulation is associated with low worker security due to substantial differences in labour market security and flexibility across EU countries. Noja (2018) also focused on the relationship between labour productivity and flexicurity, but only in CEE countries. She found that increasing resilience through fixed-term and temporary contracts and a higher engagement in education and training, combined with more extensive spending on active labour market measures, positively impact labour productivity. 


\section{Journal of Contemporary Management Issues}

Unemployment benefit programmes may encourage people who receive benefits to try less hard to find a new job than they otherwise would. This side effect occurs for two reasons. The first is that during the maximum benefit period, the advantage of finding a job is smaller for someone receiving benefits. If one is not receiving benefits, the more significant benefit is usually the wages for the new job. With eligibility for unemployment benefits, this advantage is reduced to the difference between the wage paid for a new job and the unemployment benefit, primarily because payments stop when someone finds a job. This is called the moral hazard because individuals adjust their behaviour after becoming eligible for unemployment benefits. The second reason is a liquidity constraint problem, where individuals may be forced to take a job with lower pay or a job that does not match their skills rather than wait until they find more suitable employment. The unemployment compensation programme removes this pressure and allows unemployed individuals to maintain their consumption without having to accept unsuitable work (Moffitt, 2014). This has also been highlighted by Behar (2009). In addition, it also strengthens their bargaining position, allowing them to bid up the equilibrium wage at the cost of higher unemployment benefits. The presence of minimum wages or unemployment benefits may make the efficient labour supply curve more resilient for workers with lower wages. Mrnjavac and Blažević (2014) argue that employers will allocate more significant amounts to paying contributions when the minimum wage is raised, which positively impacts the government budget. However, the minimum wage effects may indirectly affect and disrupt in the long run, which may contribute to an increase in government spending through social transfers. This means that the increase in the minimum wage may lead to the dismissal of workers, which, together with the likely difficulties in finding a new job, could discourage workers and consequently lead to an increase in PLMP expenditure.

The evidence on the comprehensive effect of unemployment assistance programmes on job search and unemployment duration is extensive. It indicates a positive effect on unemployment duration and a negative effect on job search. Studies typically examine either the effect of the level of unemployment benefits, generally in the form of a wage replacement ratio, or the effect of the maximum duration of benefit receipt (Moffitt, 2014). The higher the value of the wage replacement ratio (a percentage of the unemployed person's net income relative to their previous after-tax income), the higher the long-term unemployment rate because the incentives to work become lower. This situation is called an unemployment trap (Hančlova et al., 2016). Numerous studies also show that longer maximum benefit duration and higher unemployment benefits increase unemployment (see, for example, Card et al., 2015; Gonshorowski and Greszler, 2020). Increasing unemployment benefits increases the incentives for people not in the labour market to look for a job, but it also gives unemployed people an incentive to remain unemployed. Although labour force participation increases when unemployment benefits are higher, the unemployment rate also increases because more people are looking for work (Chiahui, 2020).

Moreover, increasing the duration of unemployment benefits may have an opposite effect on job supply. Namely, more generous unemployment benefits increase wages mainly because they are more selective in their job search, making employers less willing to advertise jobs. To find a suitable employer, unemployed workers have 
to search longer for a job because there are fewer vacancies in the labour market (Gonshorowski and Greszler, 2020).

On the other hand, high tax rates can create disincentives to work and cause unemployment or an inactivity trap (Tomić, 2020). Moreover, high tax wedges make unemployment and work in the informal sector more attractive (Behar, 2009). The tax wedge on labour costs is defined as the income tax on gross wage income, supplemented by employee and employer social security contributions, stated as a share of total labour costs. Tvrdon (2011) confirms the positive effect of a high tax burden on long-term unemployment. Similar conclusions are found in a study by Bassanini and Duval (2009) for a sample of 21 OECD countries. The researchers confirm that a combination of a high tax wedge and a longer duration of unemployment benefits increases aggregate unemployment and reduces employment opportunities.

In contrast, highly coordinated and centralised wage bargaining systems are predicted to lower unemployment rates. Using a sample of EU member states, Gora et al. (2006) showed adverse effects of the tax wedge on employment growth. They also provided evidence that the tax wedge has a more substantial impact on employment rates for low-skilled workers. The negative impact of a higher tax wedge on labour force participation and employment rates were also shown by Vork et al. (2007) and Dolenc et al. (2011).

The effects of passive labour market policies (PLMPs) on labour market performance are ambiguous. On the one hand, they play an essential role in ensuring the social standard of the unemployed; on the other hand, they can easily lead to inefficiencies in job placement, reduce the intensity of job search and lower the motivation of the unemployed (see, for example, Fialova and Schneider, 2009; Laporšek and Dolenc, 2012). In Slovenia, spending on ALMPs is three times lower than on PLMPs (Laporšek, 2020).

The effects of ALMPs have been intensively analysed and summarised in numerous meta-analyses (Card et al., 2017; Crepon and van den Berg, 2016; Kluve, 2010). The stronger linkage between income support and ALMPs has recently become a global trend. This originates from recognising that guaranteeing support to income cannot improve an individual social situation or employment status (Martin, 2014). Interventions are considered adequate if they motivate or activate the unemployed to find suitable employment more quickly. Their main objective is the (re)integration of unemployed persons. Generally, they are a combination of measures aimed at jobseekers to improve and adapt their skills, competencies, and knowledge and, consequently, promote job creation. The measures also include support for career counselling and direct job search, skills development and various training (Peyron Bista and Carter, 2017).

Several studies have considered general economic factors such as gross domestic product, labour productivity, wages, and union density as additional variables to explain the effectiveness of labour market policies (Gonzalez Carreras et al., 2015; Južnik Rotar, 2018; Martin, 2014; Card et al., 2015). Researchers (Bassanini and Duval, 2009; Martin, 2014; Murtin et al., 2013; Sahnoun and Abennadher, 2020) suggest that active labour market policies reduce unemployment and long-term unemployment. Južnik Rotar (2018), who estimated the impact of spending on labour market policies on the unemployment rate, also found that spending on ALMPs harms the 


\section{Journal of Contemporary Management Issues}

unemployment rate, while the impact of expenditures on PLMPs on the unemployment rate is positive, suggesting that spending on PLMPs is not effectively allocated.

The relationship between labour market performance and flexicurity policy components was studied by Laporšek and Dolenc (2012). The sample included 20 EU countries over the period 1990 to 2008. The results showed that spending on ALMPs is positively associated with labour market outcomes due to their positive impact on human capital. In contrast, generous PLMPs have adverse effects on the transition to employment. A micro-econometric evaluation by Burger et al. (2017) shows that ALMPs in Slovenia perform relatively well when cost-effectiveness and effects on labour market outcomes are considered. To increase the effectiveness of ALMPs, Slovenia should improve activation measures by introducing mandatory participation in ALMPs for recipients of unemployment benefits who are unemployed for a more extended period (Vodopivec et al., 2017). The degree of flexibility in the labour market is also reflected in the share of part-time and temporary employment. There is a strong segmentation between workers with fixed-term contracts and those with permanent contracts in Slovenia. The largest share of fixed-term contracts in Slovenia is found among young people. Such forms of employment remove barriers to transition between jobs and transition out of unemployment or economic inactivity (Hančlova et al., 2016; Pánková, 2005; Haltiwanger et al., 2014; Micco and Pages, 2006).

\section{METHODOLOGY}

\subsection{Data}

Based on the literature review, our data vector consists of GDP per capita in EUR at current prices (v1), unemployment rate (v2), long-term unemployment rate (v3), participation rate $(\mathrm{v} 4)$, the employment rate (v5), the part-time employment rate (v6), the temporary employment rate (v7), trade union density in \% (v8), labour productivity as GDP per hour worked (v9), average gross annual wage in EUR (v10), average gross monthly salary in EUR (v11), public expenditure on ALMP as a percentage of GDP (v12), public spending on PLMP as a percentage of GDP (v13), public expenditure on total labour market policies as a percentage of GDP (v14), the average annual number of cash social assistance benefits paid (v15), and the average annual number of recipients of unemployment benefit (v16).

The data for our empirical investigation were obtained from various database sources. Data for variables v1 to v7 come from the Eurostat database, for variables v8 to v11 from the OECD database, for variables v12 to v14 from the D.G. Employment, Social Affairs, and Inclusion database, while the data for variables v15 and v16 come from the Employment Service of the Republic of Slovenia database. Data were collected on an annual basis for the period 1995-2017. The descriptive statistics for the variables are presented in Table 1. 
Table 1. Descriptive statistics

\begin{tabular}{|c|l|l|}
\hline Variable & Mean & Std. dev. \\
\hline v1 & $14,858.48$ & $3,906.22$ \\
\hline v2 & 7.10 & 1.43 \\
\hline v3 & 49.21 & 7.08 \\
\hline v4 & 70.05 & 1.95 \\
\hline v5 & 64.99 & 2.09 \\
\hline v6 & 7.98 & 1.79 \\
\hline v7 & 13.38 & 2.13 \\
\hline v8 & 34.22 & 10.29 \\
\hline v9 & 30.89 & 8.51 \\
\hline v10 & $16,660.93$ & $5,568.58$ \\
\hline v11 & $1,388.41$ & 464.05 \\
\hline v12 & 0.30 & 0.09 \\
\hline v13 & 0.55 & 0.22 \\
\hline v14 & 0.85 & 0.29 \\
\hline v15 & $50,749.75$ & $6,149.59$ \\
\hline v16 & $25,638.22$ & $7,597.96$ \\
\hline
\end{tabular}

Source: Authors' calculations.

\subsection{Methods}

To define the underlying dimensions of unemployment benefits, we use the principal component approach. This approach involves determining what linear components exist in the existing data and how a particular variable might contribute to that component (Field, 2009). The goal is to reduce the size of a data set and reduce it to an actual underlying dimensionality. This means reducing the large group of variables to fewer previously unknown dimensions (components).

The components identified were used in further least-squares analysis to determine the relationship between each component (denoted $\mathrm{K}$ in the regression function) and unemployment benefits (denoted U.B. in the regression function). The Statistical Package for the Social Sciences (SPSS) was used for the calculations. The fundamental regression function, where $\alpha$ is an intercept, $\beta s$ are regression coefficients, and $\varepsilon$ is an error term, can be written as follows:

\section{RESULTS}

We proceeded with the principal component approach, using a correlation matrix as input, through which standardisation is automatically performed to deal with different units of measurement. Bartlett's test for sphericity (p-value $<0.05$ ) and KMO statistic $0.612(>0.5)$ indicate that the analysis is reasonable. 


\section{Journal of Contemporary Management Issues}

Table 2. Total variance explained

\begin{tabular}{|c|c|c|c|c|c|c|}
\hline \multirow{2}{*}{ Component } & \multicolumn{5}{|c|}{ Initial Eigenvalues } & \multicolumn{3}{|c|}{ Rotation Sums of Squared Loadings } \\
\cline { 2 - 7 } & Total & \% of Variance & Cumulative \% & Total & \% of Variance & Cumulative \% \\
\hline 1 & 8.11 & 54.06 & 54.06 & 5.67 & 37.81 & 37.81 \\
\hline 2 & 3.43 & 22.84 & 76.90 & 4.69 & 31.27 & 69.08 \\
\hline 3 & 1.64 & 10.96 & 87.86 & 2.82 & 18.78 & 87.86 \\
\hline 4 & 0.86 & 5.74 & 93.60 & & & \\
\hline 5 & 0.63 & 4.19 & 97.79 & & & \\
\hline 6 & 0.18 & 1.23 & 99.02 & & & \\
\hline 7 & 0.08 & 0.56 & 99.58 & & & \\
\hline 8 & 0.04 & 0.27 & 99.84 & & & \\
\hline 9 & 0.02 & 0.10 & 99.95 & & & \\
\hline 10 & 0.01 & 0.05 & 100.00 & & & \\
\hline 11 & 0.00 & 0.00 & 100.00 & & & \\
\hline 12 & 0.00 & 0.00 & 100.00 & & & \\
\hline 13 & 0.00 & 0.00 & 100.00 & & & \\
\hline 14 & 0.00 & 0.00 & 100.00 & & & \\
\hline 15 & 0.00 & 0.00 & 100.00 & & & \\
\hline
\end{tabular}

Source: Authors' calculations.

Table 2 shows that the first component explains $54.06 \%$ of the total variance and that the first three components together explain $87.86 \%$ of the total variance. The scree plot (Figure 1) also provides information on the number of components to be obtained. However, we decided that three components were the correct number for the analysis. 
Figure 1. Scree plot

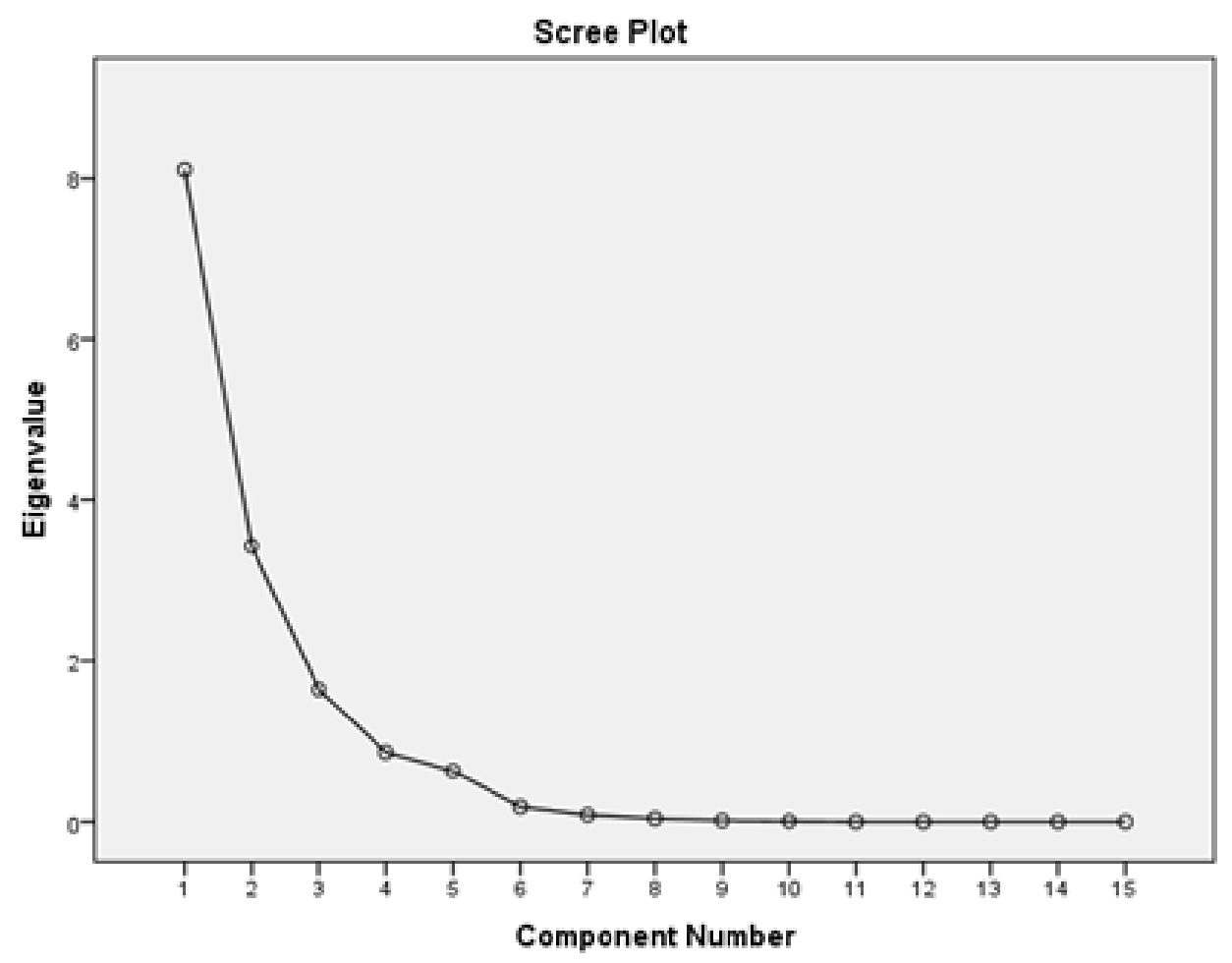

Source: Authors' calculations.

Based on the results of the rotated component matrix (table 3), we define three underlying dimensions of unemployment benefits, namely the general economic environment (component 1), social protection (component 2) and functioning of the labour market (component 3), allowing for variable weights above 0.6 . Component 1 is a linear combination of variables $\mathrm{v} 1, \mathrm{v} 8 \mathrm{-v} 11$ and v15. Component 2 is a linear combination of variables v6, v7, v12-v14, whereas component 3 is a linear combination of variables v2-v5. 


\section{Journal of Contemporary Management Issues}

Table 3. Rotated component matrix

\begin{tabular}{|c|c|c|c|}
\hline \multirow{2}{*}{} & \multicolumn{3}{|c|}{ Component } \\
\cline { 2 - 4 } & $\mathbf{1}$ & $\mathbf{2}$ & $\mathbf{3}$ \\
\hline $\mathrm{v} 1$ & 0.97 & 0.12 & -0.16 \\
\hline $\mathrm{v} 8$ & -0.91 & -0.36 & -0.15 \\
\hline $\mathrm{v} 9$ & 0.90 & 0.26 & 0.34 \\
\hline v10 & 0.88 & 0.46 & 0.06 \\
\hline v11 & 0.88 & 0.46 & 0.06 \\
\hline v15 & -0.74 & 0.06 & 0.27 \\
\hline v12 & 0.03 & 0.92 & -0.05 \\
\hline v14 & 0.25 & 0.92 & 0.19 \\
\hline v13 & 0.33 & 0.83 & 0.27 \\
\hline v7 & -0.16 & -0.71 & -0.04 \\
\hline v6 & 0.60 & 0.67 & 0.05 \\
\hline v3 & -0.03 & -0.20 & 0.91 \\
\hline v5 & -0.07 & -0.54 & -0.83 \\
\hline v2 & 0.34 & 0.59 & 0.71 \\
\hline v4 & 0.55 & -0.17 & -0.67 \\
\hline
\end{tabular}

Source: Author's calculations.

Each component thus defined was then used in a regression analysis to determine the relationship between each component and unemployment compensation. The regression model according to the F-test proves to be statistically significant ( $p$ value $<0.05)$ with $R^{2} 0.88$. The results obtained (Table 4), considering standardised coefficients, show, first, that the worse the general economic environment, the greater the pressure on unemployment benefits ( $\mathrm{p}$ value $<0.05$ ). Second, the more generous the social protection in the labour market is, the higher the pressure on unemployment benefits $(p$-value $<0.05)$ is. Third, a non-functioning labour market increases the pressure on unemployment benefits, the last effect being borderline and has not been statistically significant. 
Table 4. Estimation of coefficients

\begin{tabular}{|l|l|l|l|l|l|l|}
\hline \multirow{2}{*}{$\begin{array}{l}\text { Model } \\
\text { B }\end{array}$} & \multicolumn{2}{|l|}{ Unstandardised Coefficients } & Standardised Coefficients & \multirow{2}{*}{ t } & Sig. \\
\cline { 2 - 7 } & Std. Error & Beta & & & \\
\hline \multirow{2}{*}{1} & (constant) & $24,233.00$ & 943.74 & & 25.68 & .000 \\
\cline { 2 - 7 } & component 3 & $1,784.16$ & 985.70 & 0.22 & 1.81 & .108 \\
\cline { 2 - 7 } & component 2 & $6,743.27$ & 985.70 & 0.83 & 6.84 & .000 \\
\cline { 2 - 7 } & component 1 & $3,008.75$ & 985.70 & 0.37 & 3.05 & .016 \\
\hline
\end{tabular}

Source: Authors' calculations.

\section{DISCUSSION AND IMPLICATIONS}

Slovenia offers a comprehensive social protection system. The Unemployment Insurance Programme is part of PLMPs and provides financial assistance for unemployment. Those who are not eligible for unemployment benefits may apply for social assistance. Unemployment does not only affect unemployed people. The extent and duration of unemployment have far-reaching effects on the entire economy. Workers lose income while output and consumption decline. The results show that the pressure on unemployment benefits is more significant during poor economic conditions. The study period includes crisis years, which could bias the results.

Countries attempt to mitigate labour market failures through various regulations, and the most important is employment policy. Within such a policy, active and passive labour market policies are available. ALMP is primarily an attempt to strengthen the link between active and passive labour market policies and to equate social protection policies and employment in general. The aim is to shape activation policies within a common framework. On the other hand, PLMP is especially important in economic crisis, as it replaces lost personal income and serves as a basic safety net to the unemployed.

The main shortcoming of the system is that it does not encourage active job search, although the rights and obligations of benefit recipients are relatively strict. The primary condition for a person to be eligible for benefits is the obligation to participate in the labour market actively. The academic background suggests that unemployment insurance systems cause differences in unemployed individuals' behaviour (Williamson, 2006). They determine their equilibrium outcome from the preferences of job seekers and the wages offered by employers, also known as reservation wages. It allows them to weigh the possible positives and negatives between remaining unemployed and finding a job. More generous benefits lead to an increase in the recipient's reservation wage and less intensive job search compared with unemployed workers who are not eligible for unemployment benefits since remaining unemployed under a more generous system is less costly. Several studies (Hornstein in Lubik, 2015; Marinescu and Skandalis, 2018; Rothstein, 2011; Schmeider et al., 2015; Južnik Rotar and Krsnik, 2020; Tatsiramos and Ours, 2012) confirm that this leads to a decrease 


\section{Journal of Contemporary Management Issues}

in employment levels and an increase in the duration of unemployment. The results also show that the more generous social protection is, the higher pressure on unemployment benefits.

In addition, labour market activity concerns macroeconomic effects such as the long-term unemployment rate, labour force participation and their links to aggregate supply and demand. Long-term unemployment was a noticeable problem in Slovenia even before the financial crisis, and it accounts for about half of all unemployed. The results of many studies indicate that the duration of unemployment is significantly longer for recipients of unemployment benefits than for the unemployed who are not entitled to compensation. In addition to the period of entitlement to unemployment benefits, the level of benefits also has an important influence on the longer time spent looking for a new job. On the one hand, a more generous unemployment benefit system increases pressure for higher wages. As a result, companies are unwilling to hire workers, while the unemployed have difficulties finding a job.

On the other hand, a more generous unemployment benefit system may lead to less intensive job search because it is better to stay at home than to work, as the opportunity cost is are lower (Fujita 2010; Kyyrä and Pesola, 2017). Overall, the results obtained suggest that a non-functioning labour market increases the pressure on unemployment benefits. However, the effect is not statistically significant.

According to our analysis, some approaches to labour market policy decisionmaking can be defined to improve the performance of the Slovenian labour market. In designing a flexicurity system, Slovenia needs to pay more attention to creating appropriate work incentives. Unemployment benefits and social transfers, combined with high-income taxation, can discourage the unemployed from finding employment (Fialová and Schneider, 2009; Laporšek and Dolenc, 2012). Compared to other countries, the unemployment trap in Slovenia is very high in the initial phase of unemployment. The unemployment trap indicator shows the difference in a person's net earnings from unemployment to employment. This difference results from social contributions, higher taxes and lower social transfers when employed than higher social transfers and payments when unemployed. It has increased over the last decade and means a lower motivation to work. Therefore, social security systems need to be redesigned to enable faster reintegration into the labour market. This means strengthening measures to prevent the transition to long-term unemployment, which usually leads to inactivity and, thus, slower economic development, as the country fails to realise its full potential.

The design of a social security system and the choice of different parameters, such as benefit levels and duration, is about finding the right balance between protecting the unemployed and avoiding too much distortion of work incentives (Schmeider and Wachter, 2016). Policies should primarily focus on increasing the responsiveness of the employment service, which could be significant in preventing inactivity among the unemployed. Dealing with the unemployed is of great importance to a person's success in returning to the labour market. Accordingly, they should strive to provide adequate education, counselling, and communication to encourage individuals to seek employment actively. Particular attention should be paid to older unemployed people, who make up the highest proportion among the long-term unemployed, the low-skilled, and recipients of unemployment benefits. It 
would be necessary to support these measures with an effective ALMP, as financial compensation alone cannot motivate individuals to find work. PLMP over a long period with no or few active programmes leads to more long-term unemployed (O’Higgins, 2010). Evidence-based policymaking should be encouraged. Measuring outcomes and evaluating programmes are of great importance. Otherwise, we cannot know which policies or programmes are effective and which only alleviate social problems and therefore do not positively impact individual development, even if they cost the country a lot of money.

\subsection{Enterprise-level implications}

The global financial crisis has impacted all types of businesses, small and large, due to tight credit conditions, lower demand, and general uncertainty and fear. Increased unemployment also impacts companies as they are burdened with taxes, further affecting their business and operations. Under these circumstances, businesses have no interest in hiring new workers. In addition, Hagedorn et al. (2013) found that unemployment benefits lead to a decrease in job creation by employers because they cause an increase in the equilibrium wage. As a result, firms' accounting profits decline and job postings are reduced to restore the equilibrium relationship between the cost of entry and expected profits. In addition, when revenues and profits decline, companies must limit or eliminate hiring. This means that more work has to be done by fewer people. While this leads to an increase in productivity per employee, on the other hand, working conditions become more arduous, wage increases are halted, and workers may fear further layoffs.

To reduce costs and improve the overall situation, companies may cut spending on research and development, stop introducing new products, and stop buying new equipment, which is critical in enhancing sales and increasing market share. Spending on marketing and advertising may also be cut. Declining GDP also negatively impacts consumer confidence and spending, affecting business performance. Declining aggregate demand also most likely leads to business closures, especially for newly open businesses (Geroski et al., 2010), allowing surviving companies to capture higher market share.

Corporate strategy and performance depend on capabilities and resources, management's perception of opportunities and risks, and the overall cultural, market, institutional, and organisational situation (Sternad, 2012). The financial, product and labour markets in which companies operate, their acute sense of economic deterioration, and other institutional conditions, such as the nature of government support for business and their performance, have a significant impact on how companies adjust to recession conditions and their future performance.

To leverage their capabilities, companies can use different strategies, such as portfolio strategy (new product development, alliances, acquisitions, divestments), growth strategy (consolidation, entry into new markets, withdrawal, new product introduction), financing strategy (e.g., debt restructuring, equity raising), and business strategy (cost focus, differentiation, or hybrid) (Kitching et al., 2009). Circumstances or resources often constrain the choice of strategy. Kitching et al. (2009) found that larger companies are more sensitive to their choice of strategy because of their better resource base and greater flexibility in the face of environmental shocks. 


\section{Journal of Contemporary Management Issues}

Companies' network of relationships with other stakeholders or competitors affects corporate strategy and performance. For example, companies operating in markets that require continuous product innovation face pressure to innovate even in times of recession, which often requires uninterrupted investment in intellectual property and R\&D. Companies with limited resources that are unable to allocate sufficient assets may have difficulty spending heavily on investment strategies (see, for example, Raisch and Birkinshaw, 2008). On the contrary, companies have to weigh which price is more likely to lead to higher sales in price-sensitive markets, especially when competitors have lower prices.

Companies that adapt faster and better have a higher probability of surviving the dire economic situation and positioning themselves well in the market (Pajunen, 2008; Soininen et al., 2012). Increased risks and uncertainties, rapid changes in the globalisation of the economy, communication, changes within markets and technology force companies to respond and adapt to such influences. Moreover, a favourable business environment signals workers to increase their confidence and invest in additional skills and competencies that companies need to develop or maintain their competitive advantage.

\section{CONCLUSION}

Social transfers have many different effects on the labour market and how the unemployed behave in other circumstances. For example, a higher value of unemployment causes the reservation wage of the unemployed to increase. The unemployed become choosier in their choices and wait for a better offer. They may also be less motivated to look for work, especially if they receive unemployment benefits for a more extended period.

Many different factors influence the number of people receiving unemployment benefits. This paper defines the underlying dimensions of unemployment benefits in Slovenia using the principal component approach. Using the principal component approach, we defined three components of unemployment benefits referred to as the general economic environment, social protection, and functioning of the labour market. Each component so defined was then used in the regression analysis to determine the relationship with unemployment benefits. The results show that the general economic environment, social protection and functioning of the labour market are essential components of unemployment benefits, with the first two proving to be significant.

The Slovenian social security system is quite generous. Unemployment benefits and social transfers combined with high tax rates create strong incentives to work. Slovenia should therefore promote the transition from nonemployment to employment, focusing on the most vulnerable groups. It would be necessary to reduce the population's dependence on social benefits and ensure social security to a greater extent through employment. We emphasise that social security systems should be redesigned to promote activation and optimise faster reintegration into the labour market. Evidence-based policymaking should be encouraged to use public resources effectively. Moreover, companies can hardly be expected to hire new workers without an improved business environment. 


\section{REFERENCES}

1. Bassanini, A., Duval, R. (2009): Unemployment, institutions and reform complementarities: reassessing the aggregate evidence for OECD countries. Oxford Review of Economic Policy, 25(1), 40-59.

2. Behar, A. (2009): Tax Wedges, Unemployment Benefits and Labour Market Outcomes in the New E.U. Members. AUCO Czech Economic Review, 3, 69-92.

3. Behrendt, C. (2013): Investing in people: Implementing the extension of social security through national social protection floors. In: Kucera, D. and Islam, I. (Ed.): Beyond macroeconomic stability: Structural transformation and inclusive development. Genea: ILO, 228-261.

4. Bekker, S. (2018): Flexicurity in the European Semester: still a relevant policy concept? Journal of European Public Policy, 25(2), 175-192.

5. Berg. J., Salerno, M. (2008): The origins of unemployment insurance: Lessons for developing countries. In: Berg, J. and Kucera, D. (Ed.): In defence of labour market institutions: Cultivating justice in the developing world. Geneva: ILO.

6. Bouis, R., Causa, O., Demmou, L., Duval, R., Zdzienicka, A. (2012): The Short-Term Effects of Structural Reforms [working paper]. Paris: OECD Economics Department.

7. Burger, A., Vodopivec, M., Laporšek, S., Vodopivec, M. (2017): Impact evaluation of key employment programmes in Slovenia. Ljubljana: Ministry of Labour, Family, Social Affairs and Equal Opportunities.

8. Card, D., Johnston, A., Leung, P., Mas, A., Pei, Z. (2015): The Impact of Unemployment Benefits on the Duration of Unemployment Insurance Receipt: Evidence from a Regression Kink Design in Missouri 2003-2013. American Economic Review, 105(5), 126-156.

9. Card, D., Kluve, J., Weber, A. (2017): What works? A meta analysis of recent active labor market program evaluations. Journal of the European Economic Association, 16(3), 894-931.

10. Card, D., Kluve, J., Weber, A. (2015): What works? A meta analysis of recent active labour market program evaluations [working paper]. Cambridge: National Bureau of Economic Research.

11. Chia-hui, L. (2020): Labor participation externalities and unemployment. Economics Bulletin, 40(2), 1002-1010.

12. Crepon, B., van den Berg, G. J. (2016): Active labor market policies. Annual Review of Economics, 8, 521-546.

13. Dolenc, P., Laporšek, S., Šeparović, A. (2011). Does Labour Taxation affect Unemployment? Croatian worker in international perspective. Ekonomska istraživanja, 24(3), 86-101.

14. Fialova, K., Schneider, O. (2009): Labor Market Institutions and their Effect on Labor Market Performance in the New E.U. Member Countries. Easteren European Economics, 47(3), 57-83.

15. Field, A. P. (2009): Discovering statistics using SPSS. London: Sage.

16. Fujita, S. (2010): Economic Effects of the Unemployment Insurance Benefit. Business Review, 4, 20-27.

17. Geroski, P. A., Mata, J., Portugal, P. (2010): Founding Conditions and the Survival of New Firms. Strategic Management Journal, 31(5), 510-529. 


\section{Journal of Contemporary Management Issues}

18. Gonshorowski, D., Greszler, R. (2020): The Impact of Additional Unemployment Insurance Benefits on Employment and Economic Recovery: How the \$600-per-Week Bonus Could Backfire. Washington: The Heritage Foundation.

19. Gonzalez Carreras, F. J., Kirchner Sala, L., Speckesser, S. (2015): The effectiveness of policies to combat youth unemployment [working paper]. Brighton: University of Brighton.

20. Gora, M., Rdziwill, A., Sowa, A., Walewski, M. (2006): Tax Wedge and Skills: Case of Poland in International Perspective. Warsaw: Centre for Social and Economic Research.

21. Hagedorn, M., Karahan, F., Manovskii, I., Mitman, K. (2013): Unemployment benefits and unemployment in the Great recession: The role of macro effects [working paper]. Cambridge: National Bureau of Economic Research.

22. Haltiwanger, J., Scarpetta, S., Schweiger, H. (2014): Cross Country Differences in Job Reallocation: The Role of Industry, Firm Size and Regulations. Labour Economics, 26, 11-25.

23. Hančlova, H., Šimek, M., Horak, J. (2016): Factors influencing the longterm unemployment level and development in the European Union. Proceedings of 30th International Conference Mathematical Methods in Economics, 249-254.

24. Hornstein, A., Lubik, T. A. (2015): The Rise in Long Term Unemployment: Potential Causes and Implications. Economic Quarterly, 101(2), 125-149.

25. ILO. (2017): World Social Protection Report 2017-2019: Universal social protection to achieve Sustainable Development Goals. Geneva: ILO.

26. Južnik Rotar, L. (2011): Ocenjevanje učinkov aktivne politike zaposlovanja. Revija Management, 6(2), 165-176.

27. Južnik Rotar, L. (2018): The Effects of Expenditures for Labour Market Policy on Unemployment Rate. Business Systems Research, 9(1), 55-64.

28. Južnik Rotar, L., Krsnik, S. (2020). Analysing the Relationship between Unemployment Benefits and Unemployment Duration. Society and Economy, 42(3), 280-297.

29. Kajzer, A. (2015): Prvi učinki sprememb regulacije trga dela iz leta 2013 na segmentacijo in fleksibilnost tega trga v Sloveniji. IB Revija, 2(XLIX), $37-44$.

30. Kitching, J., Blackburn, R., Smallbone, D., Dixon, S. (2009). Business strategies and performance during difficult economic conditions. London: Department for Business Innovation and Skills.

31. Kluve, J. (2010): The effectiveness of European active labor market programs. Labour Economics, 17, 904-918.

32. Kyyrä, T., Pesola, H. (2017): The Effects of U.I. Benefits on Unemployment and Subsequent Outcomes: Evidence from Kinked Benefit Rule [discussion paper]. Bonn: IZA Institute of Labour Economics.

33. Laporšek, S. (2020): Implementation of flexicurity in Slovenia. Review of Innovation and competitiveness, 6(1), 21-48.

34. Laporšek, S., Dolenc, P. (2011). The analysis of flexicurity in the E.U. member states. Transylvanian Review of Administrative Sciences, 32, 125-145. 
35. Laporšek, S., Dolenc, P. (2012). Do Flexicurity Policies Affect Labour Market Outcomes? An Analysis of E.U. Countries. Revija za socijalnu politiku, 19(2), 107-129.

36. Marinescu, I., Skandalis, D. (2018): Unemployment Insurance and Job Search Behaviour. https://ssrn.com/abstract $=3303367$ (accessed in November 2018).

37. Martin, J. P. (2014): Activation and active labour market policies in OECD countries: Stylised facts and evidence on their effectiveness [policy paper]. Bonn: IZA Institute of Labour Economics.

38. Micco, A., Pages. C. (2006): The Economic Effects of Employment Protection: Evidence from International Industry-Level Data [discussion paper]. Bonn: IZA Institute of Labour Economics.

39. Moffitt, R. A. (2014): Unemployment benefits and unemployment. IZA World of Labour, 13, 1-10.

40. Mrnjavac, Ž., Blažević, S. (2014): Is minimum wage a good policy for poor workers in Croatia? Management Journal of Contemporary Management Issues, 19 (1), 17-43.

41. Murtin, F., De Serres, A., Hijzen, A. (2013): The ins and outs of unemployment: The Role of Labour Market Institutions [working paper]. Paris: OECD Publishing.

42. Noja, G. G. (2018): Flexicurity models and productivity interference in C. E. E. countries: a new approach based on cluster and spatial analysis. Economic Research - Ekonomska Istraživanja, 31(1), 111-1136.

43. O'Higgins, N. (2010): The Impact of the Economic and Financial Crisis on Youth Employment: Measures for Labour Market Recovery in the European Union, Canada and the United States. Geneva: ILO.

44. Owyang, M. T., Sekhposyan, T. (2012): Okun's Law over the Business Cycle: Was the Great Recession All That Different? Federal Reserve Bank of St. Louis Review, 94(5), 399-418.

45. Pajunen, K. (2008): Institutions and inflows of foreign direct investment: a fuzzy-set analysis. Journal of International Business Studies, 39(4), 652-669.

46. Pánková, V. (2005): Tobinovo Q - teorie a aplikace. Politicka ekonomie, LIII(5), 601-608.

47. Peyron Bista, C., Carter, J. (2017): Unemployment protection: A good practices guide and training package: Experience from ASEAN. Bangkok: ILO.

48. Raisch, S., Birkinshaw, J. (2008): Organisational

Ambidexterity:

Antecedents, Outcomes, and Moderators. Journal of Management, 34(3), 375-409.

49. Rothstein, J. (2011): Unemployment Insurance and Job Search in the Great Recession. Brookings Papers on Economic Activity, 42(2), 143-213.

50. Sahnoun, M., Abdennadher, C. (2020): A simultaneous-equation model of active labour market policies and change in unemployment rate: evidence from OECD countries. Policy Studies, DOI: 10.1080/01442872.2020.1754384

51. Schmeider, J. F., Wachter, T., Bender, S. (2015): The Effect of Unemployment Benefits and Nonemployment Durations on Wages. American Economic Review, 106(3), 739-777.

52. Schmeider, J. F., Wachter, T. (2016): The Effects of Unemployment 


\title{
Journal of Contemporary Management Issues
}

Insurance Benefits: New Evidence and Interpretation. Annual Review of Economics, 8(1), 547-581.

53. Soininen, J., Puumalainen, K., Sjörgren, H., Syrjä, P. (2012): The impact of global economic crisis on SMEs: Does entrepreneurial orientation matter? Management Research Review, 35(10), 927-944.

54. Sternad, D. (2012): Adaptive Strategies in Response to the Economic Crisis: A Cross-Cultural Study in Austria and Slovenia. Managing Global Transitions, 10(3), 257-282.

55. Tatsiramos, K., Ours, J. C. (2012): Labour Market Effect of Unemployment Insurance Design. Journal of Economic Surveys, 28(2), 284-311.

56. Tomić, I. (2020): Employment protection reforms and labour market outcomes in the aftermath of the recession: Evidence from Croatia. Public Sector Economics, 44(1), 3-39.

57. Tvrdon, M. (2011): Unemployment as the macroeconomic problem: the case of Visegrad Group countries. International Journal of Systems Applications, Engineering \& Development, 5(2), 187-197.

58. Vodopivec, M. Cvörnjek, N., Laporšek, S., Vodopivec, M. (2017): Activation policies in cash benefit programmes for the unemployed. Ljubljana: Ministry of Labour, Family, Social Affairs and Equal Opportunities.

59. Vodopivec, M., Laporšek, S., Vodopivec, M. (2017): Equity Effects of The New Law on Labour Relations in Slovenia. Ljubljana: Ministry of Labour, Family, Social Affairs and Equal Opportunities.

60. Vork, A., Leetmaa, R., Paulus, A., Anspal, S. (2007): Tax benefit System in the New Member States and their Impact on Labour Supply and Employment [working paper]. Tallinn: PRAXIS Center for Policy Studies.

61. Williamson, S. D. (2006): Macroeconomics. International Edition. Harlow: Pearson Education.

\section{ANALIZA KLJUČNIH DIMENZIJA NAKNADA ZA NEZAPOSLENE U SLOVENIJI I IMPLIKACIJE NA RAZINI PODUZEĆA}

\begin{abstract}
Sažetak
Cilj je ovog rada utvrditi ključne dimenzije naknada za nezaposlene u Sloveniji, koristeći pristup temeljnih komponenti. Utvrdili smo postojanje triju determinanti naknada za nezaposlene: opće gospodarsko okruženje, razinu socijalne zaštite $i$ funkcioniranje tržišta rada. Rezultati istraživanja pokazuju da nerazvijenost gospodarskog okruženja, kao i razina socijalne zaštite

povećavaju pritisak na naknade za nezaposlene. Loše funkcioniranje tržišta rada također povećava pritisak na naknade za nezaposlene, iako navedeni efekt nije statistički značajan.

Ključne riječi: tržište rada, nezaposlenost, socijalni transferi, naknade za nezaposlene, politika tržišta rada
\end{abstract}

